American Journal of Biochemistry and Biotechnology 7 (2): 63-69, 2011

ISSN 1553-3468

(C) 2011 M.H. Mahfouz et al., This open access article is distributed under a Creative Commons Attribution

(CC-BY) 3.0 license

\title{
Effects of L-Carnitine and Cinnamon Extract Treatment on Lens Crystallins of Rats Fed High Fructose Diet
}

\author{
${ }^{1}$ Mohamed H. Mahfouz, ${ }^{2}$ Amany Abd El-Ghaffar, \\ ${ }^{3}$ Mona A. Mohamed and ${ }^{4}$ Hala M. Ghanem \\ ${ }^{1}$ Department of Biochemistry, National Institute of \\ Diabetes and Endocrinology, Cairo, Egypt \\ ${ }^{2}$ Department of Biochemistry, Research Institute of Ophthalmology, Giza, Egypt \\ ${ }^{3}$ Department of Chemistry, Biochemistry Division, Faculty of Science, \\ Al-Azhar University, Egypt \\ ${ }^{4}$ Department of Biochemistry, Faculty of Science, Ain Shams University, Egypt
}

\begin{abstract}
Problem statement: Rats fed high dietary fructose are documented to form an acquired model of insulin resistance; the present study aims to investigate possible changes in lens crystallins of rats fed high fructose diet and the effects of administration of each exogenous L-Carnitine (CA) and Cinnamon Extract (CE) on protein glycation, oxidative stress and redox homeostasis in this rat model. Approach: A total number of 60 male Wister rats of body weight 120-160 g were divided into 4 groups of 15 rats each. Group 1 received control diet, while groups 2, 3 and 4: rats received high fructose diet $(60 \mathrm{~g} / 100 \mathrm{~g}$ diet). After 2 weeks from fructose feeding, animals of group 3 were treated with L-carnitine (300 $\mathrm{mg} \mathrm{g}^{-1}$ body weight/day i.p.), while animals of group 4 were treated with cinnamon extract $(0.5 \mathrm{~mL} / \mathrm{rat} / \mathrm{day}$ orally). At the end of experimental period (30 days), serum levels of glucose and insulin were determined. Lenses of each animal were dissected; molecular weights of crystalline, oxidative stress markers, early glycation of lens proteins and carbonyl group were assayed. Results: A significant decline in antioxidants and increase in lipid peroxidation products, protein oxidation and protein glycation were observed in lens samples obtained from fructose-fed rats. Administration of each CA and CE to fructose-fed rats significantly attenuated oxidative damage and protein glycation and returned levels of antioxidants to near those in control group. Chromatographic analysis of lens crystalline of rats fed high fructose diet showed diffused peaks, indicating crystalline aggregation. Conclusion: The results of the present study indicate that dietary fructose disturbs lens integrity and administration of L-carnitine or cinnamon extract may safeguard the lens by minimizing the protein aggregation, preventing glycation and oxidative stress in animals fed high fructose diet. L-carnitine has more potent effects than $\mathrm{CE}$ in this animal model.
\end{abstract}

Key words: Insulin resistance, L-carnitine, cinnamon extract, lens crystalline, oxidative stress, protein glycation, Lens crystalline, fructose diet, Cinnamon bark, Protein carbonyl measurement, Serum glucose

\section{INTRODUCTION}

High dosage of fructose in the diet $(60 \mathrm{~g} / 100 \mathrm{~g}$ diet $)$ has been documented in literatures to induce Insulin Resistance (IR) accompanied by deleterious metabolic consequences including hyperglycemia and hyperinsulinemia in animals (Rajasckar et al., 2005; Kannappan et al., 2006; Mahfouz et al., 2010). Fructose feeding in addition to producing subtile changes in glucose and lipid metabolism creates an oxidant-antioxidant imbalance in cells and tissues (Nandhini et al., 2002).

Herbert et al. (1999) reported the effect of moderate and severe levels of diabetes on the optical performance of the rat lens and evaluated the effect of dietary fructose on diabetic lens damage. Under conditions of severe hyperglycemia, high fructose intake promotes the development of cataracts in the lens of eye. Bell et al. (2000) and Balasaraswathi et al. (2008) reported that dietary fructose disturbs lens integrity.

Corresponding Author: Mohamed H. Mahfouz, Department of Biochemistry, National Institute of Diabetes and Endocrinology, Cairo, Egypt Tel: +202 24090447 
L- carnitine ( $\beta$-hydroxy- $\gamma$-trimethylaminobutyrate, CA) is biosynthesized from amino acids lysine and methionine and also obtained from the diet. The major biochemical function of $\mathrm{CA}$ is the transport of longchain fatty acids across the inner mitochondrial membrane into the matrix for $\beta$-oxidation and has effects on oxidative metabolism of glucose in tissues (Broderick et al., 1992; Rajasckar et al., 2006).

Cinnamon bark has long been used as herbal medicine and has been shown to have the highest bioactivity (Mang et al., 2006). Animal studies have indicated that cinnamon may mimic insulin effect and this may improve glucose utilization (Qin et al., 2004; Verspohl et al., 2005) and has antioxidant properties.

Previous studies showed that administration of either carnitine or cinnamon extract improves whole-body insulin sensitivity and attenuate oxidative stress, lipid abnormalities and inflammatory markers in fructose fed rat tissues as liver and muscles (Mang et al., 2006; Mahfouz et al., 2009). Although extensive studies have been performed investigating the effects of fructose-induced IR on various organs (Mohamed 2010; Ghanem 2010), data on lens integrity and composition in this rat model are lacking (Balasaraswathi et al., 2008). Therefore, the present study was undertaken to assess the effects of administration of either L-carnitine or cinnamon extract on soluble lens crystalline, oxidative stress and protein bound sugar in rats fed high fructose diet.

\section{MATERIALS AND METHODS}

Chemicals and plant: L-Carnitine, other chemicals and solvents were of high analytical grads and were purchased from Sigma Chemical Company.

Cinnamon bark was purchased from the local market. The bark was dried and finely powdered in mechanical mixer. Exactly 10 grams of finally powdered cinnamon was dissolved in $100 \mathrm{~mL}$ distilled water in a water bath at $60^{\circ} \mathrm{C}$ for two $\mathrm{h}$ and filtered. This extract was diluted (1:10) and administered orally to rats (Kannappan et al., 2006).

Animals and experimental design: Adult male Wister rats of body weight ranging 120-160 g were used in this study. They were purchased from the breeding unit of the Egyptian Organization for Biological Products and Vaccines (Helwan, Egypt). They were housed 2/cage under controlled condition of $12 \mathrm{~h}$ light/ $12 \mathrm{~h}$ dark cycle. All animals received standard pellet diet for one week and water ad libitum. Approval had been taken from the
Research Ethical Committee of General Organization of Teaching Hospitals and Institutes, Cairo, Egypt.

After acclimatization, animals were divided into the following groups consisting of 15 rats for each:

Group 1 (CON): animals received the control diet and tap water ad libitum. The control diet contained corn starch $(60 \%)$ as the sole source of carbohydrate, $20 \%$ casein, $0.7 \%$ methionine and 5\% ground nut oil, $10.5 \%$ wheat bran and $3.5 \%$ salt mixture. Vitamin mixture $(0.2$ $\mathrm{mL}$ ) was added per one kilogram feed.

Group 2 (FRU): animals received the fructoseenriched diet and water ad libitum. The high fructose diet was similar in composition to the control diet except that starch was replaced by fructose (Rajasekar and Anuradha, 2007).

Group 3 (FRU+CA): animals received the fructosediet and tap water ad libitum. After 2 weeks Lcarnitine $(300 \mathrm{mg} / \mathrm{kg} /$ day i.p.) was administrated.

Group 4 (FRU+ CE): animals received the fructosediet and tap water ad libitum. After 2 weeks animals were treated orally with $\mathrm{CE}(0.5 \mathrm{~mL} / \mathrm{rat} /$ day $)$ (Kannappan et al., 2006).

Blood sampling and processing: All animals were maintained in their respective groups for 30 days. Blood samples from animals were collected by sin ocular puncture and serum was separated for analysis of glucose and insulin. Serum glucose was assayed by glucose oxidase method (Barham and Trinder, 1972), while insulin level was determined by monoclonal immunoradiometric assay using kit supplied by Diagnostic Products Corporation (DPC) (Marschner et al., 1974). Model Assessment (HOMA) was calculated according to Matthews et al. (1985).

Preparation of lens for analysis: The animals were scarified and the eye balls were removed. Both lenses were separated from eye balls and were rapidly desiccated, washed with saline and carefully dried over fine filter paper, weighed and placed in clean sterilized vials and kept at $-20^{\circ} \mathrm{C}$ until analysis. A lens homogenate was prepared from both lenses of each animal in $5 \mathrm{M}$ phosphate buffer $\mathrm{pH} 7.5\left(0.4 \mathrm{~g} \mathrm{~mL}^{-1}\right)$. The homogenate was centrifuged at $6000 \mathrm{rpm}$ for $10 \mathrm{~min}$ and the supernatant was separated and then used for assaying.

Determination of malondialdehyde and reduced glutathione in lens: Malondialdehyde (MDA), an end product of lipid per oxidation was estimated in the lens homogenate by colorimetric methods of Satoh (1978). 
The level of reduced glutathione was determined in lens homogenate prepared in $1 \mathrm{ml}$ of $10 \%$ Trichloroacetic Acid (TCA) according to the method of Ellman (1959) modified by Xu et al. (1992).

Protein carbonyl measurement: Levels of protein carbonyl were measured according to the method of Levine et al. (1990). The lens was homogenized in $10 \%$ (TCA) and after centrifugation; the pellet was treated with $1 \mathrm{~mL}$ of $2 \%$ (W/V) Dinitrophenyl Hydrazine (DNPH) in $2 \mathrm{~N} \mathrm{HCl}$ or with $1 \mathrm{~mL}$ of $2 \mathrm{~N} \mathrm{HCl}$ as a control. Samples were incubated at room temperature and stirred for $5 \mathrm{~min}$ intervals. Two hundred micro liters of 50\% TCA were then added and the precipitated proteins were subsequently washed three times with 1:1 ethanol-ethyl acetate and three times with $10 \%$ TCA. The final precipitate was dissolved in $6 \mathrm{M}$ guanidine and the different spectra of the DNPH derivatives versus $\mathrm{HCl}$ controls was followed spectrophotometrically at $340-370 \mathrm{~nm}$ with a scan program. The concentrations of the carbonyl groups were calculated from the absorbance spectrum using $21.5 \mathrm{mM} \mathrm{cm}^{-1}$ as the extinction coefficient for aliphatic hydrazones.

Protein measurement: Lens protein was assayed using the method described by Lowry et al. (1951). Quantification of glycation (early product) was determined according to the method of Fluckiger and Winterhalter (1976) as modified by Vidal and CabezasCerrato (1989).

Chromatographic analysis of lens crystallins: Pools of three pairs of rat lenses were homogenized in distilled water $(0.2 \mathrm{~g}$ lens $/ 2.5 \mathrm{~mL}$ distilled water $)$ and centrifuged in a cooling centrifuged at $8000 \mathrm{rpm}$ for 20 min the supernatant was subjected to column chromatographic analysis according to the method of Testa et al. (1965). The column used was $(2.6 \times 100 \mathrm{~cm})$, packed with sephadex $\mathrm{G}_{200}$. The mobile phase used was Tris buffer $\mathrm{pH} 7.5$. Fractions of $8 \mathrm{~mL} / 20 \mathrm{~min}$ were collected using a fraction collector (Universal fraction collector Eldex, USA). The optical density of collected fractions was measured using spectrophotometer (Type Uvikan 930 of Kout Ron) at $280 \mathrm{~nm}$. The elution pattern was drawn by plotting the fraction number against the optical density of each fraction. The column was calibrated using standard proteins: carbonic anhydrase (29KDa), egg albumin (45 KDa), bovine serum albumin $(66 \mathrm{KDa})$, aldolase $(158 \mathrm{KDa})$, ferritin (440 KDa) and thyroglubuline $(669 \mathrm{KDa})$. The Ve/Vo was plotted as a function of logarithm of their respective molecular weights as a standard linear plot (Fig. 1).

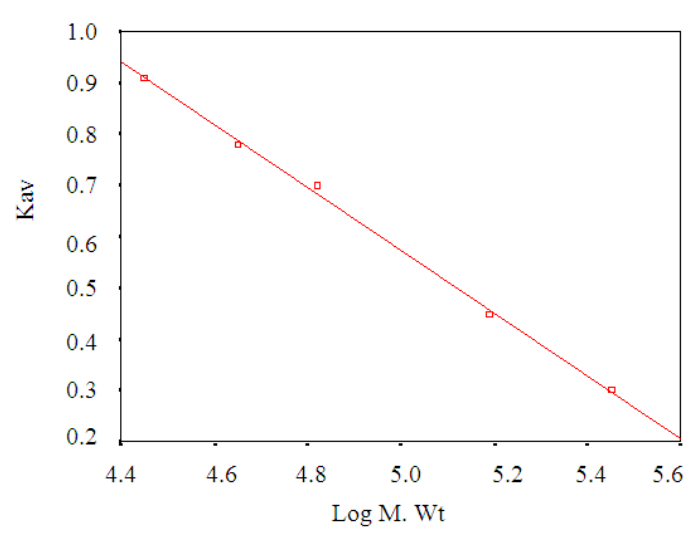

Fig. 1: Calibration curve for Kav of different standard Proteins versus log molecular weight

Statistical analysis: Values were given as the mean \pm SD. The significance of the differences in mean values between groups was analyzed using ANOVA followed by Duncan's multiple range test (DMRT). The level of statistical significance was set at $\mathrm{p} \leq 0.05$ (Dawson and Trapp, 2001).

\section{RESULTS}

The fructose fed rats developed hyperinsulinemia and hyperglycemia with increased HOMA index which were prevented by carnitine and cinnamon extract administration (Table 1).

Table 2 summarized the levels of malondialdehyde and reduced glutathione in lenses of rats fed-high fructose diet. A highly significant increase in the level of MDA and pronounced decrease in the level of reduced GSH ( $<<0.05$ for each) were observed in FRU group compared to control group. After treatment with CAR or CE, the levels of MDA and GSH returned nearly to the control levels.

As shown in Table 3, feeding high fructose diet caused an increase in both early glycated product and the carbonyl content $(\mathrm{p}<0.05)$, compared to their levels in control rats. Administration of CA to rats fed high fructose diet attenuated the pervious parameters near to the control levels. Although CE reduced early glycated product and the carbonyl content in high fructose fed rats, their levels still significantly higher than control.

The chromatographic elusion pattern of lens homogenate of control rats showed four distinct bands namely $\alpha, \beta_{1}, \beta_{2}$ and $\gamma$ crystalline (Fig. 2-a). These bands were distinct and clear. The pattern obtained for rats fed high fructose diet was different (Fig.2-b). 
Am. J. Biochem. \& Biotech., 7 (2): 63-69, 2011

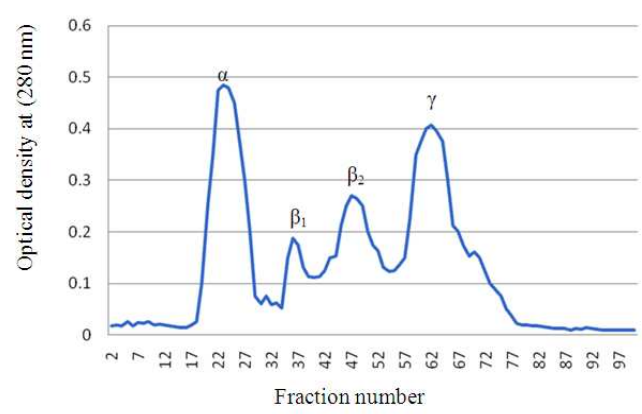

(a)

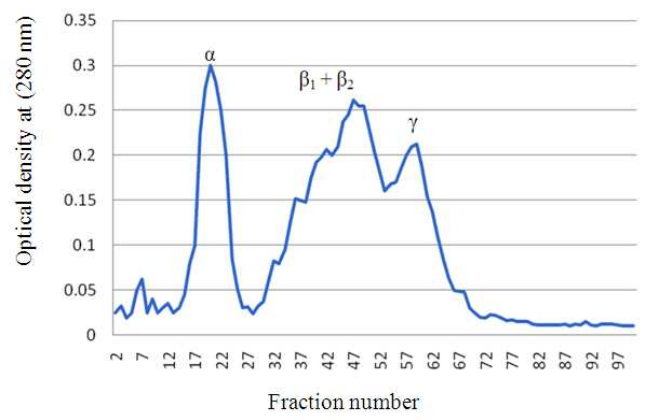

(b)

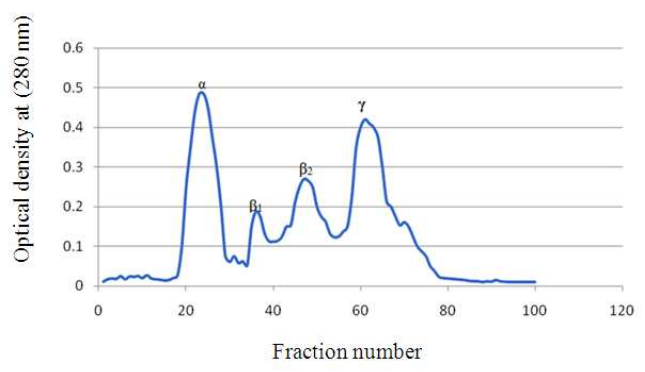

(c)

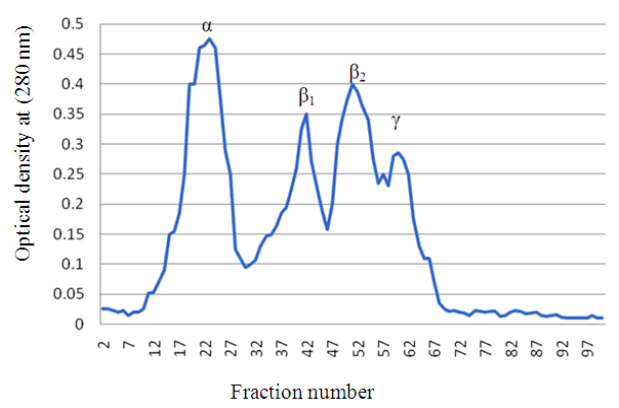

(d)

Fig 2: Chromatographic elution pattern of lens crystalline (a) Rats fed control diet (b) Rats fed high fructose die (c) Rats fed FRU + CA (d): Rats fed FRU + CE
Table 1: Serum levels of fasting glucose, insulin and HOMA index in control rats and those fed high fructose diet (FRU), treated with carnitine (FRU+CA) or cinnamon extract (FRU+CE)

\begin{tabular}{llll}
\hline Groups & $\begin{array}{l}\text { Glucose } \\
(\mathrm{mg} / \mathrm{dL})\end{array}$ & Insulin $(\mathrm{U} / \mathrm{L})$ & HOMA index \\
\hline Control & $85.7 \pm 13.0$ & $17.0 \pm 2.5$ & $3.12 \pm 0.74$ \\
FRU & $138.4 \pm 16.2^{\mathrm{a}}$ & $36.7 \pm 5.1^{\mathrm{a}}$ & $10.73 \pm 2.67^{\mathrm{a}}$ \\
FRU + CA & $67.5 \pm 13.4^{\mathrm{b}, \mathrm{c}}$ & $22.9 \pm 3.5^{\mathrm{b}, \mathrm{c}}$ & $4.1 \pm 0.81^{\mathrm{b}, \mathrm{c}}$ \\
FRU + CE & $79.1 \pm 3.7^{\mathrm{b}}$ & $14.7 \pm 1.3^{\mathrm{b}}$ & $3.2 \pm 0.78^{\mathrm{b}}$ \\
\hline
\end{tabular}

a: $p<0.01$ Vs. CON; b: p<0.05 Vs. FRU; c: p<0.05 Vs. CON

Table 2: Levels of MDA and reduced glutathione (GSH) in rat lens of control rats and those fed high fructose diet (FRU), treated with carnitine (FRU+CA) or cinnamon extract (FRU+CE)

\begin{tabular}{lll}
\hline Groups & MDA $(\mathrm{nmol} / \mathrm{g}$ lens $)$ & GSH $(\mu \mathrm{mol} / \mathrm{g}$ lens $)$ \\
\hline Control & $0.84 \pm 0.45$ & $3.93 \pm 0.59$ \\
FRU & $1.59 \pm 0.48^{\mathrm{a}}$ & $1.75 \pm 0.15^{\mathrm{a}}$ \\
FRU + CA & $0.82 \pm 0.50^{\mathrm{b}}$ & $3.17 \pm 0.76^{\mathrm{b}, \mathrm{c}}$ \\
FRU + CE & $0.82 \pm 0.66^{\mathrm{b}}$ & $2.2 \pm 0.53^{\mathrm{a}}$ \\
\hline $\mathrm{a}: \mathrm{p}<0.05$ Vs. CON; b: $\mathrm{p}<0.05$ Vs. FRU; c: $\mathrm{p}<0.05$ Vs. FRU+CE
\end{tabular}

Table 3: Early glycated products and carbonyl content in rat lens of control rats and those fed high fructose diet (FRU), treated with carnitine (FRU+CA) or cinnamon extract (FRU+CE)

\begin{tabular}{lll}
\hline Group's & Early glycated products & Carbonyl content \\
\hline & $(\mathrm{nmol} / \mathrm{mg}$ protein $)$ & $(\mu \mathrm{mol} / \mathrm{mg}$ protein $)$ \\
Control & $0.17 \pm 0.06$ & $2.30 \pm 0.45$ \\
FRU & $0.57 \pm 0.25^{\mathrm{a}}$ & $4.25 \pm 1.04^{\mathrm{a}}$ \\
FRU + CA & $0.22 \pm 0.067^{\mathrm{c}}$ & $2.65 \pm 0.99^{\mathrm{c}}$ \\
FRU + CE & $0.36 \pm 0.11^{\mathrm{a}, \mathrm{b}}$ & $3.72 \pm 1.1^{\mathrm{b}}$ \\
\hline
\end{tabular}

a: $p<0.05$ Vs. CON; b: p<0.05 Vs. FRU; c: p<0.01 Vs. FRU

Clear bands ( $\alpha$ and $\gamma$ ) were observed but the other two bands $(\beta 1$ and $\beta 2$ ) were diffused together. Administration of either $\mathrm{CA}$ or $\mathrm{CE}$ to rats fed high fructose diet corrected to some extent the diffusion which was caused by high dosage of fructose (Fig. 2c and d, respectively), which means that both rendered the bands corresponding to $\beta 1$, $\beta 2$ and $\gamma$ crystallins once again distinct and not diffused. The patterns were near to that of controls.

The protein content of each peak was calculated from the surface area under the peaks. Percentage distribution of proteins under each peak (Table 4) for rats fed high fructose diet was different from control animals. The most remarkable observations were the decrease in the percentage of $\alpha$ - crystalline $(22.28 \%)$ and $\gamma$ crystalline $(25.22 \%)$. Also lower values of protein contents were observed in $\alpha$ - crystalline $(40.10 \mathrm{mg} / \mathrm{g}$ wet wt) and $\gamma$ crystalline $(45.39 \mathrm{mg} / \mathrm{g}$ wet wt) in fructose fed rats, compared to $85.55 \mathrm{mg} / \mathrm{g}$ wet wt for $\alpha$ fraction and $111.10 \mathrm{mg} / \mathrm{g}$ wet wt for $\gamma$-crystalline of control animals (Table 5). Treatment with CA and CE to rats fed high fructose diet mitigated this protein contents nearly to the controls values.

Table 6 shows the approximate range of molecular weights of different crystallins in the experimental groups and treated rats. Calibration of the column was performed with standard proteins with molecular weights ranging from 669.000-29.000 KDa (Fig. 1). 
Table 4: Percentage value of different lens crystalline fractions of control rats and those fed high fructose diet (FRU), treated with carnitine (FRU+CA) or cinnamon extract (FRU+CE)

\begin{tabular}{|c|c|c|c|c|}
\hline \multirow[b]{2}{*}{ Groups } & \multicolumn{4}{|c|}{ Crystallins (\%) } \\
\hline & $\alpha$ & $\beta_{1}$ & $\beta_{2}$ & $\gamma$ \\
\hline Control & 29.01 & 9.68 & 23.66 & 37.65 \\
\hline FRU & 22.28 & 52.50 & & 25.22 \\
\hline $\mathrm{FRU}+\mathrm{CA}$ & 29.80 & 8.65 & 17.30 & 44.20 \\
\hline $\mathrm{FRU}+\mathrm{CE}$ & 29.00 & 23.00 & 31.50 & 16.50 \\
\hline
\end{tabular}

Table 5: Protein content of lens crystalline and their fractions in control rats and those fed high fructose diet (FRU), treated with carnitine (FRU+CA) or cinnamon extract (FRU+CE)

\begin{tabular}{lllllr}
\hline & & \multicolumn{3}{l}{ Crystallins } & \\
Groups & $(\mathrm{mg} / \mathrm{g}$ wet wt) & $\alpha$ & $\beta_{1}$ & $\beta_{2}$ & \multicolumn{1}{c}{$\gamma$} \\
\hline Control & 295 & 85.55 & 28.55 & 69.80 & 111.10 \\
FRU & 180 & 40.10 & 94.50 & & 45.39 \\
FRU + CA & 285 & 84.90 & 24.60 & 49.30 & 125.40 \\
FRU + CE & 233 & 67.00 & 55.00 & 73.00 & 38.00 \\
\hline
\end{tabular}

Table 6: Molecular weights (KDa) of different lens crystallins control rats and those fed high fructose diet (FRU), treated with carnitine (FRU+CA) or cinnamon extract (FRU+CE)

\begin{tabular}{|c|c|c|c|c|}
\hline \multirow[b]{2}{*}{ Groups } & \multicolumn{4}{|c|}{ Crystallins } \\
\hline & $\alpha$ & $\beta_{1}$ & $\beta_{2}$ & $\gamma$ \\
\hline Control & 831.76 & 371.54 & 186.21 & 70.80 \\
\hline FRU & 1000.00 & 186.21 & & 87.10 \\
\hline $\mathrm{FRU}+\mathrm{CA}$ & 831.76 & 371.54 & 208.93 & 70.80 \\
\hline $\mathrm{FRU}+\mathrm{CE}$ & 831.76 & 251.19 & 141.25 & 83.18 \\
\hline
\end{tabular}

The total protein content of soluble part of lens homogenate of control animals amounted to $295 \mathrm{mg} / \mathrm{g}$ wet wt (Table 5). This value drops to $180 \mathrm{mg} / \mathrm{g}$ wet $\mathrm{wt}$ in animals fed high fructose diet. Treated rats with either CA or CE caused an increase in the protein content of soluble fraction of lens homogenate until reach to 285 and $233 \mathrm{mg} \mathrm{g}^{-1}$ wet wt, respectively.

\section{DISCUSSION}

In fructose fed rats free radical production can be enhanced during hyperinsulinemia and hyperglycemia by mechanisms such as autoxidation of glucose and enhanced glycation in addition to fructose itself which can create oxidative stress (Rajasekar and Anuradha, 2007). Several investigations reported that feeding high fructose diet in rats caused enhanced production rate of reactive oxygen species which may be responsible for oxidative damage to cellular constituent and diminished anti-oxidative capacity (Nandhini et al., 2002; Busserolles et al., 2002; Rajasekar and Anuradha, 2007).

Reduced Glutathione (GSH) is synthesized in the lens and responsible for protecting the thiol groups on lens proteins, thereby preventing the cross linkage of lens crystalline which lead to cataract (Awasthi et al., 1996).

The present study shows marked decrease in the level of lens glutathione in rats fed high fructose diet compared to control group. This drop is an indication to the damage occurred in lens of rats. The enhanced level of reactive oxygen species generated by high fructose diet together with reduced level of glutathione is expected to cause formation of disulphide bonds through sulfhydryl oxidation of lens crystalline (Awasthi et al., 1996). Loss of GSH could also result from a decrease in biosynthesis because $d e$ novo synthesis of GSH requires ATP which is reduced in fructose fed rats owing to excess consumption of ATP in the formation of sugar phosphate (Balasaraswathi et al., 2008).

In this context, the enhanced formation of lipid peroxidation and protein carbonyl are indicative of generation of Reactive Oxygen Species (ROS) formation in rat's lens. Excess ROS formation, together with glycation of protein has been shown to be the major cause of lens damage (Ansari et al., 1996; Boscia et al., 2000).

The increased level of MDA may be linked mainly or secondary to the reduction of lens antioxidant content. It was known to play a role in lens opacification and can form cross-links between membrane lipids and proteins (Grattagliano et al., 1998). The increased of protein carbonyl content of the lens may indicate the oxidation state of lens proteins as a result of oxidative stress (Cheng et al., 1996). Because the uptake of fructose by cells is not regulated by insulin, an increase in fructose intake can increase fructose-3-phosphate. Cheng et al. (1996) and Lal et al., 1995) observed that phosphorylation of fructose takes place in the lens and that the phosphorylated forms of fructose are highly reactive with lens protein. Fructose3 phosphate and its breakdown product 3deoxyglucosone cause aggregation of lens crystalline (fructosylation) which increases light scatter and decreases lens transmittance (Spector, 1995).

With regard to the lens proteins, the results of the present study revealed a decline in both lens total protein and contents of the soluble fraction of the lens homogenate. This may be due to the denaturation of lens proteins especially in the contents of $\alpha$ and $\gamma$ crystallins in rats fed high fructose diet compared to those fed control diet.

The elution pattern of crystallins showed that the molecular weight of $\alpha$-crystalline increased and shifted to high value in case of rats fed high fructose diet compared to control animals. The high molecular weight aggregates enough to scatter light and contribute to the loss of lens transparency (Peluso et al., 2001). 
The transparency of the crystalline lens depends on the regular, orderly spacing of its cells and proteins. Disturbance of this order for instance due to protein aggregation, membrane degeneration or fluctuations in protein distribution results in local change of refractive index. This is the basic explanation of light scattering (Awasthi et al., 1996).

L-carnitine has a thiol and methionine sparing activity and thereby improves the total antioxidant status because methionine is an antioxidant and is also one of the precursors for GSH and CA biosynthesis (Peluso et al., 2001). Peluso et al. (2001) reported that L-carnitine prevents $\mathrm{H}_{2} \mathrm{O}_{2}$-induced opacity and protects the chaperone activity of lens $\alpha$ - crystalline which prevents protein aggregation.

Cao et al. (2007) reported that cinnamon bark alleviates the antioxidant systems by increasing the activities of antioxidant enzymes in lens of rats fed high fructose diet. Thus, the enhanced protective action of these natural antioxidants (CA and $\mathrm{CE}$ ) is clearly presented in the chromatographic elution pattern of the soluble part of the lens homogenate of these groups. The different peaks representing lens crystalline were again distinct from each other and the pattern obtained was more or less near to the control. This means that administration of either CA or CE could hinder the oxidative effects of ROS and minimized the oxidation of sulfhydride group that cause aggregation of lens crystallines and in turn development of lens opacity.

\section{CONCLUSION}

It is concluded that the results of the present study indicate that dietary fructose disturbs lens integrity and administration of either L-carnitine or cinnamon extract may safeguard the lens by preventing glycation and oxidative stress with consideration that $\mathrm{CA}$ has more potent effects than CE.

It is recommended that early introduction of CA may prevent the precataractous biochemical changes and hence delay the onset of cataract formation.

\section{REFERENCES}

Ansari, N.H., L. Wang and S.K. Srivastava, 1996. Role of lipid aldehydes in cataractogenesis: 4hydroxynonenal-induced cataract. Biochem. Mol. Med., 58: 25-30. PMID: 8809342

Awasthi S., S.K. Srivatava, J.T. Piper, S.S. Singhal and M. Chaubey et al., 1996. Curcumin protects against 4-hydroxy-2-trans-nonenal-induced cataract formation in rat lenses. J. Clin. Nutr., 64: 761-766. ISSN: 0002-9165
Balasaraswathi, K., P. Rajasekar and C.V. Anuradha, 2008. Changes in redox ratio and protein glycation in precataractous lens from fructose-fed rats: effects of exogenous L-carnitine. Clin. Exp. Pharmacol. Physiol., 35: 168-173. PMID: 17941890

Barham, D. and P. Trinder, 1972. An important colour reagent for the determination of blood glucose by the oxidase system. Analyst, 97: 142-145. PMID: 5037807

Bell, R.C., J.C. Carlson, K.C. Storr, K.L. Herbert and J.G. Sivak, 2000. High-fructose feeding of streptozotocin-diabetic rats is associated with increased cataract formation and increased oxidative stressing the kidney. Br. J. Nutr., 84: 575-82. PMID: 11103229

Boscia, F., I. Grattagliano, G. Vendemiale, T. MicelliFerrari and E. Altomare, 2000. Protein oxidation and lens opacity in humans. Invest. Ophthalmol. Vis. Sci., 41: 2461-2465. PMID: 10937554

Broderick, T.L., H.A. Quinney and G.D. Lopaschuk, 1992. Carnitine stimulation of glucose oxidation in the fatty acid perfused isolated working rat heart. J. Biol. Chem., 267: 3758-63. PMID: 1740427

Busserolles, J., E. Gueux, A. Mazur and Y. Rayssiguir, 2002. Substituting honey for refined carbohydrates protects rats from hypertriglyceridemia and prooxidative effects of fructose. J. Nutr., 132: 3379-82. http://jn.nutrition.org/content/132/11/3379.short

Cao, H., M.M. Polansky and R.A. Anderson, 2007. Cinnamon extract and polyphenols affect the expression of tristetraprolin, insulin receptor and glucose transporter 4 in mouse 3T3-L1 adipocytes. Arch. Biochem. Biophys., 459: 214-222. PMID: 17316549

Cheng, H.M., F.Y. Cheng, H. Xiong and J. Xiong, 1996. The further metabolism of sorbitol-3phosphate and fructose-3-phosphate in the mature rat lens. Ophthalmic Res., 28: 57-63. PMID: 8726678

Dawson, B. and R.G. Trapp, 2001. Basic and Clinical Biostatistics. 3rd Edn., PBL. Lange Medical Books/McGraw-Hill, USA., ISBN: 0838505104, pp: 399.

Ellman, G.L., 1959. Tissue sulfhydryl group. Arch. Biochem. Biophys., 82: 70-77. ISSN: 0003-9861

Fluckiger, R. and K.H. Winterhalter, 1976. In vitro synthesis of hemoglobin A1C. FEBS Lett., 71: 356-360. ISSN: 0014-5793

Ghanem, H.M., 2010. Amelioration of inducible nitric oxide synthase, insulin like growth factor-1 and insulin receptor substrate-1 in liver tissue of insulin resistant rats treated with L-carnitine. Am. J. Biochem. Biotech., 6: 195-203. DOI: 10.3844/ajbbsp.2010.195-203 
Grattagliano, I., G. Vendemiale, F. Boscia, T. MicelliFerrari and L. Cardia et al., 1998. Oxidative retinal products and ocular damages in diabetic patients. Free Radic. Biol. Med., 25: 369-372. PMID: 9680184

Herbert, K.L., J.G. Sivak and R.C. Bell, 1999. Effect of diabetes and fructose/non-fructose diet on the optical quality (cataracts) of the rat lens. Curr. Eye Res., 9: 305-312. PMID: 10520226

Kannappan, S., T. Jayaraman, P. Rajasekar, M.K. Ravichandran and C.V. Anuradha, 2006. Cinnamon bark extract improves glucose metabolism and lipid profile in the fructose-fed rat. Singapore Med. J., 47: 858-863. PMID: 16990960

Lal, S., B.S. Szwergold, A.H. Taylor, W.C. Randall and F. Kappler et al., 1995. Metabolism of fructose-3phosphate in the diabetic rat lens. Arch. Biochem. Biophys., 318: 191-199. PMID: 7726561

Levine, R.L., D. Garland, C.N. Oliver, A. Amici and I. Climent et al., 1990. Determination of carbonyl content in oxidatively modified proteins. Methods Enzymol., 186: 464-478. PMID: 1978225

Lowry, O.H., N.J. Rosebrough, A.L. Farr and R.J. Randall, 1951. Protein measurement with the Folin phenol reagent. J. Biol. Chem., 193: 265-275. PMID: 14907713

Mahfouz, M.H., Ghanem H.M. and G.M. Abdel, 2009 Therapeutic effect of L-carnitine on sialic acid, soluble Fas (sFas) and other biochemical variables in hyperinsulinemic rats. Life Sci. J., 6: 87-93. ISSN: 1097-8135

Mahfouz, M.H., Ghanem H.M. and G.M. Abdel, 2010. Modulation of insulin receptor substrate-1 and some inflammatory variables in hyperinsulinemic rats treated with cinnamon extract. Am. J. Biochem. Biotech., 6: 11-18. DOI: 10.3844/ajbbsp.2010.11.18

Mang, B., M. Wolters, B. Schmitt, K. Kelb and R. Lichtinghagen et al., 2006. Effects of a cinnamon extract on plasma glucose, HbAlc and serum lipids in diabetes mellitus type 2. Eur. J. Clin. Invest., 36: 340-344. PMID: 16634838

Marschner, I., P. Botter1mann, F. Erhardt, R. Linke and G. Lffler et al., 1974. Group experiments on the radioimmunological insulin determination. Horm. Metab. Res., 6: 293-296. PMID: 4413601

Matthews, D.R., J.P. Hosker, A.S. Rudenski, B.A. Naylor and D.F. Treacher et al., 1985. Homeostasis model assessment: Insulin resistance and beta-cell function from fasting plasma glucose and insulin concentrations in man. Diabetologia, 28: 412-419. DOI: $10.1007 / \mathrm{BF} 00280883$

Mohamed, M.A., 2010. Impact of L-carnitine and cinnamon on insulin-like growth factor-1 and inducible nitric oxide synthase gene expression in heart and brain of insulin resistant rats. Am. J. Biochem. Biotech., 6: 204-212. DOI: 10.3844/ajbbsp.2010.204-212

Nandhini, A.T., S.D. Balakrishnan and C.V. Anuradha, 2002. Response of liver antioxidant system to taurine in rats fed high fructose diet. Ind. J. Exp. Biol., 40: 1016-19. PMID: 12587730

Peluso, G., O. Petillo, A. Barbarisi, M.A. Melone and E. Reda, 2001. Carnitine protects the molecular chaperone activity of lens alpha-crystallin and decreases the post-translational protein modifications induced by oxidative stress. FASEB J., 15: 1604-1606. PMID: 11427500

Qin, B., M. Nagasaki, M. Ren, G. Bajotto and Y. Sato, 2004. Cinnamon extract prevents the insulin resistance induced by a high-fructose diet. Horm. Metab. Res., 36:119-125. PMID: 15002064

Rajasckar, P., Kaviarasan, S. and C.V. Anuradha, 2005. L-carnitine adminstration prevents oxidative stress in high fructose-fed insulin resistant rats. Diabetologia Croatica, 34: 21-28. ISSN: 0351-0042

Rajasckar, P., M.K. Ravichandran and C.V. Anuradha, 2006. Intraperitoneal L-carnitine regulates lipid metabolism and reduces oxidative stress in fructose-induced hyperlipidemic rats. Diabetol. Croat., 34: 87-95. ISSN: 0351-0042

Rajasekar, P. and C.V. Anuradha, 2007. Effect of LCarnitine on skeletal muscle lipids and oxidative stress in rats fed high-fructose diet. Exp. Diabetes Res., 1-8. DOI: 10.1155/2007/72741

Satoh, K., 1978. Serum lipid peroxide in cerebrovascular disorders determined by a new colorimetric method. Clin. Chim. Acta., 90: 37-43. PMID: 719890

Spector, A., 1995. Oxidative stress-induced cataract: mechanism of action. FASEB J., 9: 1173-1182. PMID: 7672510

Testa, M., G. Amand and E. Balazs, 1965. Separation of the soluble proteins of bovine lenses on polyacrylamide gels. Exper. Eye Res., 4: 327-39. DOI: 10.1016/S0014-4835(65)80048-3

Verspohl, E.J., K. Bauer and E. Neddermann, 2005. Antidiabetic effect of Cinnamomum cassia and Cinnamomum zeylanicum in vivo and in vitro. Phytother. Res., 19: 203-206. PMID: 15934022

Vidal, P. and J. Cabezas-Cerrato, 1989. Quantification of glycation-induced browning in lens crystallins. A simple method for studying the advanced products of the Maillard reaction. Ophthalmic Res., 21: 261-267. PMID: 2779978

Xu, G.T., J.S. Zigler and M.F. Lou, 1992. The possible mechanism of naphthalene cataract in rat and its prevention by an aldose reductase inhibitor (ALO1576). Exp. Eye Res., 54: 63-72. PMID: 1541342 